\title{
PRODUKSI BIBIT KAKAO (Theobroma cacao L) DENGAN PEMANFAATAN JAMUR TRICHODERMA SP. SEBAGAI DEKOMPOSER
}

\author{
Junyah Leli Isnaini' ${ }^{1)}$, Mu'minah $^{1)}$, Muhammad Yusuf ${ }^{1)}$, Firsandi ${ }^{1)}$ \\ 1) Progarm Studi Teknologi Produksi Tanaman Pangan ,Politani Pangkep \\ Jl.Poros Makassar-Pare Pare Km.83, Kecamatan Mandalle, Kab.Pangkep \\ Korespondensi: e-mail junyahleli_isnaini@yahoo.com
}

\begin{abstract}
ABSTRAK
Bibit kakao yang berkualitas diperoleh melalui pemeliharaan yang baik dengan penggunaan jamur yang bermanfaat mengoptimalkan fungsi media tanam yang mengandung bahan organik. Salah satu diantaranya adalah penggunaan jamur Trichoderma sp. Pemanfaatan Jamur Trichoderma sp.pada media tanam yang mengandung bahan organik dapat memacu pertumbuhan bibit tanaman kakao. Penelitian bertujuan untuk melihat pengaruh pemberian jamur Trichoderma sp. sebagai decomposer pada pertumbuhan bibit tanaman kakao. Terdapat dua perlakuan yaitu: pemberian jamur Trichoderma sp. $20 \mathrm{mg} /$ polybag dan tanpa pemberian jamur Trichoderma sp., yang masing-masing terdiri atas 12 unit penelitian. Data dianalisis dengan statistik sederhana. Hasil penelitian menunjukkan bahwa pemberian jamur Trichoderma sp. $20 \mathrm{mg} /$ polybag pada media tanam memberikan pengaruh terbaik terhadap pertumbuhan bibit tanaman kakao pada semua parameter yang diamati.
\end{abstract}

Kata kunci: Bibit kakao, Trichoderma sp.

\begin{abstract}
Quality cocoa seeds are obtained through proper upkeep with the use of mushrooms which are useful for optimizing the function of planting media containing organic matter. One of them is the use of the fungus Trichoderma sp. The use of Trichoderma sp. in planting media containing organic matter can spur the growth of cocoa seedlings. The aim of this research was to see the effect of giving Trichoderma sp. as a decomposer in the growth of cocoa seedlings. There are two treatments, namely: giving the fungus Trichoderma sp. $20 \mathrm{mg} /$ polybag and without Trichoderma sp. Mushroom, each consisting of 12 research units. Data were analyzed with simple statistics. The results showed that giving the fungus Trichoderma sp. $20 \mathrm{mg} /$ polybag in the planting medium gave the best effect on the growth of cocoa seedlings in all observed parameters.
\end{abstract}

Keywords: Cocoa seedlings, Trichoderma sp.

\section{PENDAHULUAN}

Kakao merupakan salah satu komoditas andalan nasional dan berperan penting bagi perekonomian Indonesia, terutama dalam penyediaan lapangan kerja,, sumber pendapatan petani dan sumber devisa bagi Negara, disamping mendorong berkembangnya agrobisnis dan 
agroindustri kakao (Zaenuddin, 2004). Pengembangan kakao di Indonesia sudah dimulai sejak awal tahun 1980-an dan perkembangannya saat ini sangat pesat. Berdasarkan Data Direktorat Jenderal Perkebunan Kementrian Pertanian menyebutkan tahun 2018 produksi kakao naik 4,12\% menjadi 686.964 ton dari produksi tahun 2017 sebesar 659.776 ton. Dari tahun 2013 produksi kakao terus mengalami kenaikan, hanya saja sempat turun di tahun 2015 sebesar 9,8\% yakni 593.331 ton dibandingkan tahun 2014 yaitu sebesar 728.414 ton (Dekaindo, 2018). Sejalan dengan perkembangan kakao, maka pemerintah terus melaksanakan berbagai usaha diantaranya perbaikan teknik budidaya yang meliputi teknik pembibitan yang efisien, usaha mendapatkan bahan tanam unggul, pengaturan jarak tanam, maupun usaha perlindungan terhadap hama dan penyakit.

Teknik pembibitan kakao yang baik merupakan salah satu aspek yang penting dalam budidaya kakao, dengan tujuan untuk dapat menghasilkan bibit siap tanam yang baik dan berkualitas, yang nantinya dapat berproduksi secara maksimal. Bibit yang berkualitas diperoleh melalui pemeliharaan yang baik, misalnya penggunaan bahan organik pada media dan pemberian pupuk..

Salah satu usaha dalam mengoptimalkan penggunaan bahan organik seperti kompos pada media tanam yaitu dengan penggunaan mikroba berupa jamur yaitu Trichoderma sp. Jamur Trichoderma sp. selain memiliki kemampuan antagonis terhadap berbagai penyakit tular tanah, juga memiliki kemampuan dekomposer bahan organik di dalam tanah. Bahan organik memiliki peran dalam menentukan kemampuan tanah untuk mendukung tanaman, sehingga jika kadar bahan organik tanah menurun maka kemampuan tanah dalam mendukung produktivitas tanaman juga menurun. Hasil penelitian Yanti (2016), bahan organik yang didekomposisi oleh Trichoderma dapat meningkatkan pertumbuhan bibit pisang dengan efektivitas 10 - $17 \%$, aplikasi kompos jerami yang didekomposisi oleh Trichodema merupakan bahan organik yang dapat menekan pertumbuhan Foc, dan aplikasi bahan organik yang didekomposisi Trichoderma mampu meningkatkan aktivitas enzim peroksidase pada bibit pisang. Selanjutnya Rangkutil dkk.. (2017), menyatakan Pengaruh pupuk kompos kotoran kambing dengan dekomposer Trichoderma sangat berpengaruh pada tinggi tanaman bayam merah. Berbeda halnya dengan penelitian Djamaan (2006) yang menggunakan pupuk kompos kotoran kambing dengan aktivator Em4 terhadap pertumbuhan tanaman selada (Lactuca sativa L.) Menurut Djamaan (2006), tinggi tanaman selada pada perlakuan pupuk kompos $124 \mathrm{~g}$ hasilnya tidak berbeda nyata dengan perlakuan pupuk kompos 31, 62 dan 93 g. Hal ini membuktikan bahwa jamur Trichoderma sangat baik digunakan dalam pembuatan pupuk kompos. Sebagaiman hasil penelitian Hilda (2013), menunjukkan bahwa pengomposan yang 
menggunakan aktivator jamur Trichoderma harzianum dan mikroba sapi mampu menurunkan kadar seslulosa sebesar 2,53\% dan menghasilkan kandugan N,P,K sebesar 0,56\%, 0,28\%, dan $1,75 \%$.

Trichoderma sp. merupakan jamur yang dapat menguntungkan bagi pertumbuhan tanaman. Jamur ini dapat berkembang biak dengan cepat pada daerah perakaran, peranan Trichoderma sp. yang mampu berkompetisi dengan jamur lain namun sekaligus berkembang baik pada perakaran menjadikan keberadaan jamur ini dapat berperan sebagai biocontrol dan meningkatkan pertumbuhan tanaman. Trichoderma sp juga banyak berperan membantu pertumbuhan tanaman dengan membantu mempercepat proses penguraian unsur hara mikro dan makro di dalam tanah yang sangat dibutuhkan oleh tanaman (Setyowati, 2003). Dari uraian di atas maka dilakukan penelitian untuk melihat pengaruh pemberian jamur Trichoderma sp. terhadap pertumbuhan bibit tanaman kakao.

\section{BAHAN DAN METODE}

Bahan yang digunakan dalam penelitian ini adalah biji kakao dari varietas MCC 01, Trichoderma sp., tanah dan pupuk kompos, polybag ukuran $17 \mathrm{~cm}$ x25 cm, karung goni, sevin, label. Alat yang digunakan antara lain cangkul, skop mini, gembor, dan timbangan analitik, kamera, alat tulis, jangka sorong, penggaris.

Metode analisis yang digunakan pada percobaan ini adalah analisis statistik sederhana dengan perlakuan; Tanpa pemberian jamur Trichoderma sp. (diberi symbol tT) dan dengan pemberian jamur Trichoderma sp. 20 gr/polybag (diberi symbol T). Masing-masing perlakuan terdiri atas 12 polybag (12 polybag dengan perlakuan pemberian jamur Trichoderma sp. dan 12 polybag tanpa menggunakan Trichoderma sp), sehingg terdapat 24 unit penelitian). Data dianalisis dengan analisis statistik sederhana yaitu menghitung rata-rata pertumbuhan bibit selama dua bulan. Parameter pengamatan yaitu; tinggi tanaman $(\mathrm{cm})$, jumlah daun (helai), diameter batang $(\mathrm{cm})$ pada saat seminggu sekali

Benih kakao klon MCC 01 disortasi untuk mendapatkan benih yang bermutu baik. Lalu benih tersebut dicuci dengan abu gosok untuk menghilangkan pulp, setelah itu benih tersebut didederkan pada wadah karung yang lembab untuk dikecambahkan.

Aplikasi Trichoderma sp.dilakukan sehari sebelum kecambah ditanam di polybag yaitu mencampurkan Trichoderma sp. sebanyak 20 gram/polybag pada lubang tanam. Kemudian kecambah tersebut (benih kakao yang radikulanya telah muncul) dipindahkan ke polybag dengan lubang tanam sedalam 2-3 cm (setengah dari ukuran biji) dengan posisi benih tegak. 
Selanjutnya dilakukan pemeliharaan berupa penyiraman. Penyiraman dilakukan 2 kali sehari yakni pada pagi dan sore hari. Pelaksanaan penyiraman harus memperhatikan kondisi tanah dan kelembaban pada polybag. Selain penyiraman, bentuk pemeliharaan yang dilakukan pada percobaan ini ialah pemberian insektisida di sekitar pertanaman.

\section{HASIL DAN PEMBAHASAN}

Pada parameter tinggi tanaman, hasil pengamatan menunjukkan bahwa pertambahan tinggi tanaman yang diberikan perlakuan Trichoderma sp. dengan dosis $20 \mathrm{mg} /$ polybag menunjukkan hasil yang lebih tinggi dari pada tanaman yang tidak diberikan perlakuan. Ratarata pertambahan tinggi tanaman $(\mathrm{cm})$ dapat dilihat pada gambar 1.

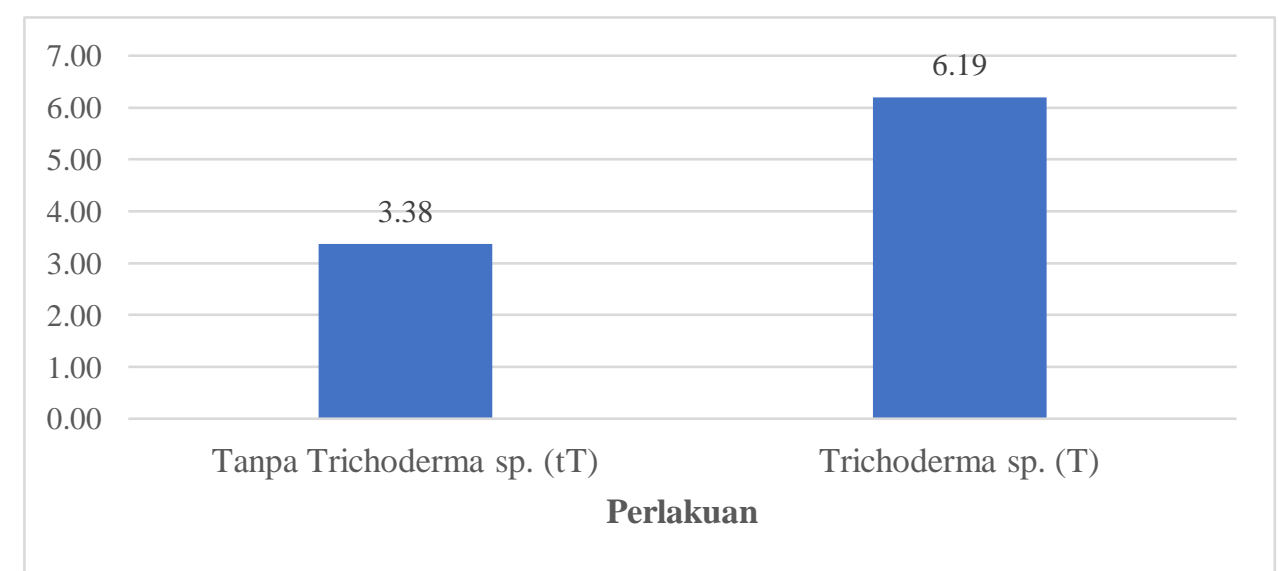

Gambar 1.Rata-rata Pertambahan Tinggi Tanaman Bibit Kakao umur 8 MST.

Pada Gambar 1 di atas menunjukkan perlakuan pemberian jamur Trichoderma sp. memberikan pengaruh terbaik dan hasil tertinggi dibanding tanaman yang tidak diberikan perlakuan serupa. Bibit tanaman kakao yang diberikan perlakuan jamur Trichoderma sp. menghasilkan rata-rata pertambahan tinggi tanaman hingga $6,19 \mathrm{~cm}$, sedangkan yang tidak diberikan Trichoderma sp., menghasilkan rata-rata pertambahan tinggi tanaman 3,38 cm.

Hasil pengamatan pada jumlah daun menunjukkan bahwa perlakuan pemberian jamur Trichoderma sp. memberikan hasil yang lebih tinggi pada pertambahan jumlah daun tanaman dibandingkan dengan perlakuan tanpa Trichoderma sp. Rata-rata pertambahan jumlah daun bibit tanaman kakao $(\mathrm{cm})$ disajikan pada gambar 2. 


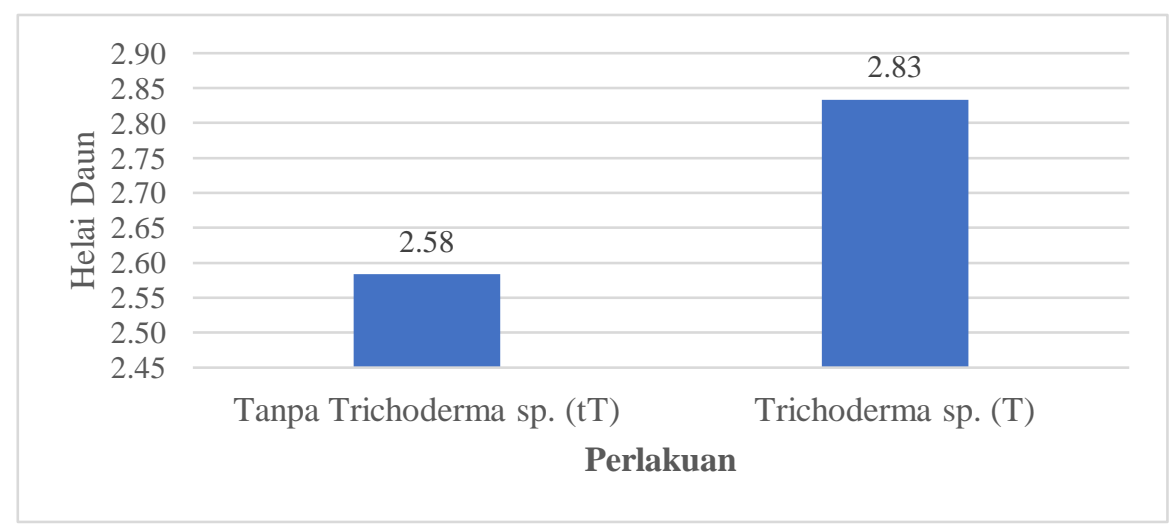

Gambar 2. Rata-rata Pertambahan Jumlah Daun Bibit kakao umur 8 MST.

Gambar 2 di atas menunjukkan bahwa rata-rata pertambahan jumlah daun pada perlakuan pemberian Trichoderma sp memberikan rata-rata pertambahan jumlah daun sebanyak 2,83 helai, sedangkan pada perlakuan tanpa Trichoderma sp memberikan rata-rata pertambahan jumlah daun hanya 2,58 helai.

Hasil Pengamatan pada diameter batang menunjukkan bahwa perlakuan pemberian jamur Trichoderma sp. memberikan rata-rata yang lebih tinggi pada pertambahan diameter batang bibit tanaman kakao dibandingkan dengan perlakuan tT (tanpa Trichoderma sp.).Hasil pertambahan diameter batang tanaman kakao dapat dilihat pada gambar 3 .

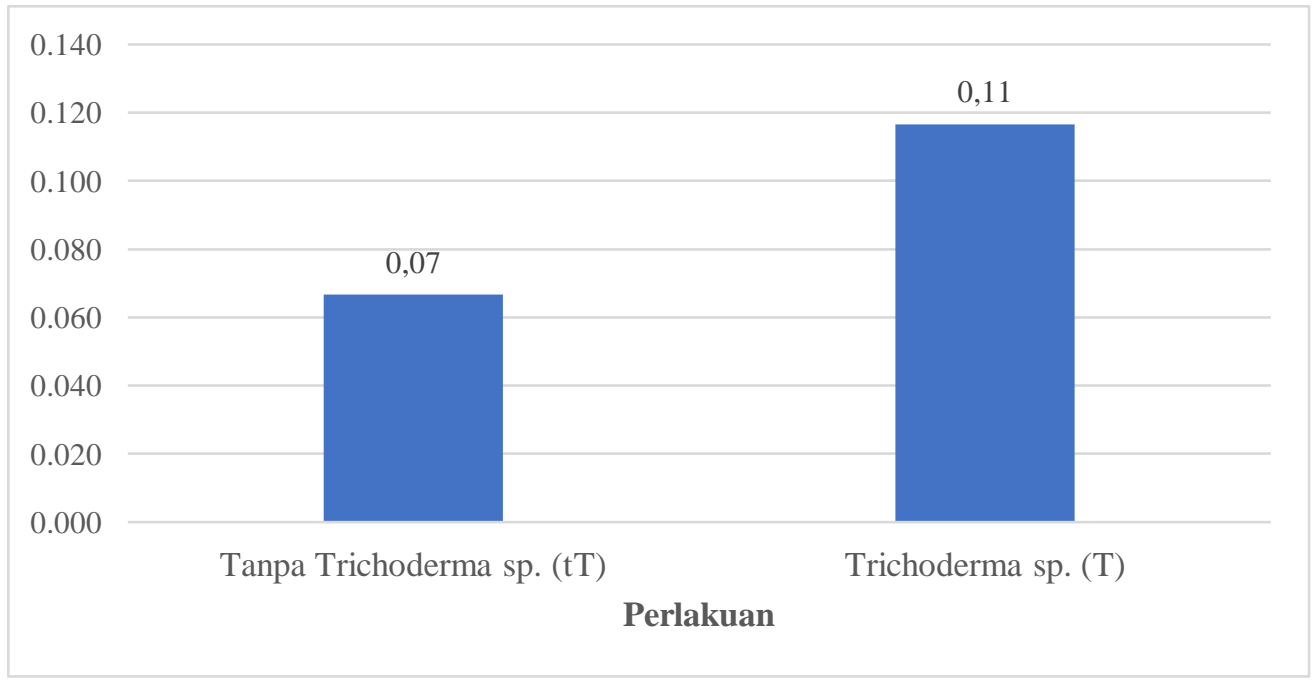

Gambar 3. Rata-rata pertambahan diameter batang $(\mathrm{cm})$ Bibit Tanaman kakao umur 8 MST. 
Gambar 3 di atas menunjukkan bahwa, rata-rata pertambahan diameter batang pada perlakuan pemberian Trichoderma sp memberikan hasil $0,11 \mathrm{~cm}$, sedangkan pada perlakuan tanpa Trichoderma sp memberikan hasil 0,07 cm.

Berdasarkan data hasil penelitian menunjukkan bahwa penggunaan jamur Trichoderma sp. secara umum mampu meningkatkan pertumbuhan bibit tanaman kakao pada semua parameter yang diamati yaitu tinggi tanaman, jumlah daun dan diameter batang. Pemberian Trichoderma sp $20 \mathrm{mg} /$ polybag pada media tanam memberikan pengaruh terbaik dan hasil yang lebih tinggi dibandingkan bibit yang tidak diberikan Trichoderma sp. Ini menunjukkan bahwa pemberian Trichoderma pada media tanam yang telah ditambahkan kompos mampu menguraikan bahan organik tersebut sehingga unsur hara yang ada dalam kompos tersebut dapat tersedia bagi tanaman. Yanti (2016) menyatakan bahan organik yang didekomposisi oleh Trichoderma dapat meningkatkan pertumbuhan bibit pisang dengan efektivitas $10-17 \%$, aplikasi kompos jerami yang didekomposisi oleh Trichodema merupakan bahan organik yang dapat menekan pertumbuhan Foc. Trichoderma mampu meningkatkan aktivitas enzim peroksidase pada bibit pisang.

Peningkatan tinggi tanaman sangat dipengaruhi oleh tersedianya unsur hara yang dibutuhkan tanaman, lingkungan yang menguntungkan dan optimalnya serapan hara oleh bibit sehingga menyebabkan pertumbuhan dan perkembangan tanaman menjadi optimal. Pemberian jamur Trichoderma sp., ke dalam tanah dapat mempercepat penguraian bahan organik, karena jamur ini dapat menghasilkan tiga enzim, yaitu 1) enzim celobiohidrolase ( $\mathrm{CBH}$ ), yang aktif merombak selulosa alami; 2) enzim endoglikonase yang aktif merombak selulosa terlarut; dan 3) enzim glukosidase yang aktif menghidrolisis unit selobiosa menjadi molekul glukosa. Enzim ini bekerja secara sinergis, sehingga penguraian dapat berlangsung lebih cepat dan intensif (Salma \& Gunarto, 1996). Proses Penguraian dapat menyebabkan tersedianya unsur hara tanah yang dibutuhkan oleh tanaman untuk pertumbuhannya seperti unsur hara nitrogen. Proses pembelahan sel akan berjalan dengan cepat dengan adanya ketersediaan Nitrogen, phosphor, dan kalium yang cukup. Nitrogen mempunyai peran utama untuk merangsang pertumbuhan secara keseluruhan dan khususnya pertumbuhan batang yang dapat memacu pertumbuhan tinggi tanaman (Sarief, 1996). Disamping itu, unsur $P$ beperan dalam proses respirasi dan metabolisme tanaman menjadi lebih baik sehingga pembentukan asam amino dan protein dapat terjadi guna pembentukan sel baru. Unsur $\mathrm{P}$ juga banyak berperan membantu pertumbuhan tanaman dengan membantu mempercepat proses penguraian unsur hara mikro dan makro di dalam tanah yang sangat dibutuhkan oleh tanaman. Sedangkan unsur K dapat membantu proses fotosintesis dan dapat merangsang pertumbuhan tanaman (Pitojo, 1995) 
Hasil pertambahan jumlah daun pada pemberian Trichoderma sp. memberikan hasil 2,83 helai. Sedangkan jumlah daun tanpa pemberian Trichoderma sp. memberikan pertambahan rata-rata 2,58 helai. Daun merupakan organ tanaman yang menentukan kelangsungan hidup tanaman, karena dalam daun terjadi proses fotosintesis, respirasi dan transpirasi. Dalam proses pertumbuhan dan perkembangan daun dipengaruhi oleh faktor genetik dari tanaman itu sendiri sehingga dapat mempengaruhi jumlah daun, selain itu ketersediaan unsur hara juga dapat mempengaruhi jumlah daun (Gardner et al., 1991). Hal ini sejalan dengan hasil penelitian Rizal et al. (2019)yang menyatakan pemberian Trichoderma sp berpengaruh sangat nyata pada pertumbuhan tinggi dan jumlah daun pada tanaman tomat karena pemanfaatan Trichoderma sp meningkatkan efisiensi pemupukan. Trichoderma sp merupakan mikroorganisme yang dikenal luas sebagai penyubur tanah. Trichoderma sp dapat berperan sebagai biodekomposer. Trichoderma sp memberikan pengaruh positif terhadap perakaran tanaman, pertumbuhan tanaman dan hasil produksi tanaman.

Pemberian Trichoderma sp. mampu meningkatkan diameter batang yang lebih besar dibandingkan dengan yang tidak diberi Trichoderma sp. Hal ini dapat terjadi karena jamur tersebut mampu menekan pertumbuhan patogen di rhizosfer perakaran, sehingga penyererapan unsur hara dapat optimal. Sebagaimana yang dikatakan oleh Setyowati (2003), Trichoderma sp. dikenal sebagai jamur agensia pengendali hayati yang memiliki kisaran inang luas. Patogen yang mampu dikendalikan oleh Trichoderma sp., antara lain: Rizoctonia solani, Fusarium oxysporum, Candida albicans, Armillaria mellea, dan Pythium aphanidermatum (Soesanto, 2008). Selanjutnya Dwiastuti et al. (2015), Trichoderma sp. mempunyai peluang tinggi untuk berkompetisi merebut tempat hidup dan sumber makanan lebih dulu, lebih cepat menembus dinding sel dan masuk ke dalam sel untuk mengambil zat makanan, serta menghasilkan antibiotik yang dapat membunuh sel cendawan pathogen. Tersedianya unsur hara dalam jumlah yang cukup menyebabkan kegiatan metabolisme dari tanaman akan meningkat demikian juga akumulasi asimilat pada daerah batang akan meningkat sehingga terjadi pembesaran pada bagian batang. Trichoderma sp mampu membantu menguraikan bahan organik dari kompos yang diperlukan tanaman untuk pertumbuhannya (Pandriyani \& Lilies, 2021). Selain dapat membantu penguraian bahan organik dan menekan pathogen di daerah perakaran, jamur Trichoderma sp kemungkinan dapat memicu hormon endogen didaerah perakaran utamanya hormone auksin. Kemungkinan dihasilkannya senyawa hormon pemacu pertumbuhan oleh jamur Trichoderma sp. didasarkan pada pendapat Salisbury \& Ross. (1995) yang menyatakan bahwa keberadaan hormon dan zat pengatur tumbuh tanaman 
tidak hanya didapatkan pada jaringan tanaman tingkat tinggi saja, tetapi juga dapat disintesis pada tingkatan mikroba. Menurut hasil penelitian Ousley et al. (1994), jamur Trichoderma sp. mampu meningkatkan pertumbuhan tanaman seperti pada mentimun (Cucumis sativus), lada (Piper nigrum), tembakau (Nicotiana sp.), dan tomat (Lycopersicum esculentum).

\section{KESIMPULAN}

Berdasarkan penelitian yang telah dilakukan, dapat disimpulkan bahwan pemberian jamur Trichoderma sp. dosis $20 \mathrm{mg} /$ polybag memberikan pengaruh terbaik dan hasil tertinggi pada bibit tanaman kakao pada semua parameter yang diamati.

\section{DAFTAR PUSTAKA}

Djamaan, D. (2006). Pengaruh Pupuk Kandang Terhadap Pertumbuhan dan Hasil Selada (Lactuca sativa L.),. Prosiding Seminar Peternakan.

Dwiastuti, M. E., Fajri, M. N., \& Yunimar. (2015). Potensi Trichoderma spp. sebagai Agens Pengendali Fusarium spp. Penyebab Penyakit Layu pada Tanaman Stroberi (Fragaria $x$ ananassa Dutch.). Jurnal Hortikultura, 25(4), 331-339.

Gardner, F. P., Peace, R. B., \& Mitchell, R. L. (1991). Fisiologi Tanaman Budidaya (Edisi Terj). Universitas Indonesia Press.

Ousley, M. A., Lynch, J. M., \& Whipps, J. M. (1994). Potential of Trichoderma spp. as consistent plant growth stimulators. Biology and Fertility of Soils, 17(2), 85-90. https://doi.org/10.1007/BF00337738

Pandriyani, \& Lilies, S. (2021). Efektifitas Pemberian dan Waktu Aplikasi Jamur Antagonis Trichoderma sp. Sebagai Pengendalian Penyakit Layu Fusarium Terhadap Pertumbuhan dan Hasil Tanaman Tomat. Jurnal Agri Peat, 12(2).

Pitojo, S. (1995). Penggunaan Urea Tablet. Penebar Swadaya.

Rangkutil, N. P. J., Mukarlina, \& Rahmawati1. (2017). Pertumbuhan Bayam Merah (Amaranthus tricolor L.) yang diberi Pupuk Kompos Kotoran Kambing dengan Dekomposer Trichoderma harzianum. Jurnal Protobiont, 6(3), 18-25. https://jurnal.untan.ac.id/index.php/ jprb/article/viewFile/20797/16920[21 Februari 2021]

Rizal, S., Novianti, D., \& Septiani, M. (2019). Pengaruh Jamur Trichoderma sp. terhadap Pertumbuhan Tanaman Tomat. Jurnal Indobiosains, 1(1).

Salisbury, F. B., \& Ross., C. W. (1995). Fisiologi Tumbuhan (I). ITB.

Salma, S., \& Gunarto, L. (1996). Aktivitas Trichoderma dalam Perombakan Selulosa. Penelitian Pertanian Tanaman Pangan. 
Sarief, S. E. (1996). Ilmu Tanah Pertanian. Pustaka Buana.

Setyowati. (2003). Penurunan Penyakit Busuk Akar dan Pertumbuhan Gulma pada Tanaman Selada yang Dipupuk Mikroba. Jurnal Ilmu-Ilmu Pertanian Indonesia, 3.

Soesanto, L. (2008). Pengantar Pengendalian Raja, Hayati Penyakit Tanaman. PT Persada, Grafindo.

Yanti, D. . (2016). Dekomposisi Berbagai Jenis Bahan Organik dengan Trichoderma viride (isolat t1sk) untuk Menginduksi Ketahanan Bibit Pisang terhadap F usariumoxysporumf. spcubense (foc) penyebab penyakit layu fusarium. Universitas Andalas.Padang.

Zaenuddin, D. R. (2004). Budidaya Kakao. Pusat Penelitian Kopi dan Kakao Indonesia. 